\title{
Role Definition and Editorial Capacity Building Status of Nigerian Christian Publishers
}

\author{
${ }^{1}$ Professor E. Nolue Emenanjo; ${ }^{2}$ Professor Ozo-Mekuri Ndimele; \\ ${ }^{3}$ Dr. Samuel Okere \\ 1, 2. University of Port Harcourt, Department of Linguistics and Communication Studies \\ 3. Babcock University, Department of Mass Communication
}

\begin{abstract}
This work is an empirical study which examines the nature of operations of Christian publishing in Nigeria with regard to role definition and editorial capacity building. It adopted the descriptive survey method using the questionnaire as instrument of data collection. From a population of 108 Christian publishers, a sample size of 97 was purposively determined out of which 88 copies of the questionnaire were retrieved. Data generated were analysed in simple descriptive statistics and presented in tables, pie chart and histogram. The findings revealed that Christian publishers in Nigeria have defined their roles appropriately but they lack the requisite editorial capacity to realise their mission. The researchers therefore, recommended, that for these publishers to be in real business of fulfilling their purpose for which they are established, they need to employ the requisite editorial staff and provide them with regular training.
\end{abstract}

Key words: Role definition; Editorial capacity building; Christian publisher

Paper Type: Research paper

\section{Introduction}

Success in the management of a publishing house depends largely on the ability of the house to define her role and the provision made for editorial capacity building. For this reason, Christian publishing houses like their counterparts in the secular domain of publishing need to invest in editorial capacity building in order to position their houses for optimum productivity (Kyomuhendo, 2002) Editorial capacity building is concerned with equipping a publishing house with manpower and operational skills. It has two major components namely, recruitment of qualified editors, and continuous training and retraining of the editors (Fasemore, 2005). When the requisite editorial staff are employed, the publishing house has the prospects of realising her goals (Adejuwon, 2003).

Nigerian publishers Association (NPA) the umbrella body for publishing organisations in Nigeria has since the last decade mounted consistent campaign on the need for publishing houses to define their roles appropriately and then equip their editorial capacity base. NPA contends that the total package of positioning a house rests on role definition, editorial staff enlistment and training opportunities for the editors.

Since NPA began this editorial capacity building campaign, there has been a noticeable improvement both in the publications output and market place presence of educational books in Nigeria. While educational publishers are maximising the editorial capacity building opportunities, it does not seem that Christian publishers in Nigeria are working in that regard. For instance, the stable of Christian literature in Nigeria shows a market that has predominantly foreign published books. The situation therefore, gives concern as to whether the indigenous Christian publishing houses are investing in editorial capacity building. This is because a conscious investment in editorial capacity building will guarantee strong participation for a publishing house in the market share of product placement and distribution. For this reason, this paper, examines the status of role definition and editorial capacity building in Nigerian publishing houses from the Christian background referred to in this paper as Christian publishers.

In addressing the topic under study, the researchers adopted the descriptive survey research method. The use of questionnaire was adopted as the instrument of data collection. The study population was made up of 108 Christian publishing houses in Nigeria that were extracted from National Bibliography of Nigeria (2009), a publication of the National Library, a major stakeholder in the Nigerian publishing environment. A sample size of 97 Christian publishing houses was purposively sampled from seven cities within five of the six geopolitical zones in the country. Out of these, 88 publishers returned copies of their questionnaire. Data obtained from these were analysed with simple descriptive statistics and presented in tables, pie chart and histogram.

This research has the objective of finding out if Christian publishers in Nigeria have defined their roles; and also, the extent, to which, they are investing in editorial capacity building in their drive to fulfil their critical mission of developing and distributing Christian literature. 


\section{Role Definition and Sustainable Publishing Effort}

The publishing house is a manufacturing industry where productivity is measured by tangible output. In whatsoever department or unit a member of staff of the publishing house is located, the response rate to the demands of such an office must be justified by concrete evidence. This is because, as a result-driven industry, output in a publishing house is seen, touched and utilised; the proceeds from which are expected to be ploughed back into the publishing house to cater for operational costs, wages and salaries, and the payment of dividend to the investors.

Consequently, every publishing house that aims at sustainability must define very clearly, its role which is the purpose for which the publishing house is established. This is to be a guide for the workforce which must work with it. That is to say, they must understand, accept and work to realise the policies, programmes, plans and goals of the publishing house which are embedded in the organisational philosophy. It is this that defines the role that the publishing house is to play as an intellectual service provider to the society. This philosophy acts as the guiding principle and the pivot on which the entire atmosphere of the publishing house hinges (Bloisi, 2003; Kroepel, 2005). Organisational philosophy sets the tone for the culture of the house. This is demonstrated in concrete terms by the formulation of the mission statement and the core values, sometimes referred to as the vision of the organisation (Cummings, 1997). It is based on these that the publishing programme and the editorial policy can be designed.

No publishing house operates in a vacuum, and no two publishing houses operate on exactly the same terms. Each has its own distinctive features which set it out as an independent organisation designed to deliver on its own goals. It is this uniqueness, which permeates the entire publishing activities of every publishing house that forecloses the philosophy of that house. Thus, the philosophy of a publishing house is revealed in the way the mission statement which is the raison d'etre for the publishing house, is couched.

This mission statement which is also called corporate mission states unequivocally, the specific thrust or purpose of the organisation, and its formulation precedes the operations of any business organization (Bagozzi, 1998; Bearden, 2001; Hill, 2008). The implication of the existence of a mission statement in a publishing house is that the workforce is provided with the general principles of the house, which it must allow to guide it in the performance of its duties. It is also based on this, that the publishing house will be judged by both its internal and external publics.

Kottler (2003, p. 91) rehearsed the five basic questions which a functional mission statement should address as espoused by the renowned management scholar, Peter Drucker:

a. What is our business?

b. Who is the customer?

c. What is of value to the customer?

d. What will our business be?

e. What should our business be?

These are questions that every publishing house should be addressing at intervals in its operational existence. A clear and thoughtful mission statement provides employees with a shared sense of purpose, direction and opportunity (Cravens \& Piercy, 2006; Noe, Hollenbeck \& Gerhart, 2000; Roman \& Cooper, 2003). Talbot (2000, p. 9) itemises the result of an effective mission statement on both the staff and the organisation:

- Striving for the same goals

- Working in accordance with the same principles

- Adhering to the same standards

- Fostering organizational morale

- Securing the organization's reputation

- Determining the character of the organization.

The vision, philosophy and indeed the goal of the publishing house are encapsulated in the mission statement and this fact makes it an imperative working document for any publishing house.

\section{Editorial Capacity Building and Publications Output}

Editorial capacity building subsists of the recruitment of the requisite editorial staff and the provision of training opportunities for them. Training is an indispensible factor in the growth and stability of any organisation including the publishing house. It plays a vital role in the improvement of the productivity level of the staff of any organisation (Yesufu, 2000). When staff is exposed to the right training, it will sure up the quality of the performance of such staff thereby bringing about better customer satisfaction and an increase in the patronage of the organisation's product. Besides, the organisation stands to reap enormous dividends such as reduction in cost, reduced turnover, human resources reserve, faster decision, continuity of effort, 
improvement in employee morale, availability of future personnel needs of the organisation, improvement in health and safety, reduced supervision, personnel growth and organisational stability (Chandan, 2000; Silver, 1981).

Editorial staff training subsists of two major categories. These are in-house and external training. Inhouse training could be practical tutelage where new entrants are attached to senior colleagues who supervise them at work and provide practical solutions to daily work puzzles. In the process, they acquire basic training as to warrant them to work fairly independently.

In-house training can also be in the form of formal seminars and workshops organised within the publishing house. Some publishing houses may have a training department that may handle this. Where such is not possible, the responsibility may be taken up by the human resources or personnel or even administration department depending on what department is available in a particular publishing house. The appropriate department may choose to enlist facilitators from within the senior cadre of editors or arrange for external facilitators. The frequency and intensity of such in-house training is dictated by the felt need and availability of fund.

Publishing houses also expose their editors to external training opportunities. This could also be in the form of workshops, seminars and lecture methods. There is always idea sharing and networking during such training sessions since the participants are often drawn from different publishing houses. Nigerian Publishers Association (NPA) organises such sessions for editors of member-firms. Each session focusing on a particular publishing function may last from one day to even a full week.

\section{Discussion of Findings}

This research paper has two objectives. These are, to find out the ability of the publishing houses to define their roles as well as to find out the direction of editorial capacity building status of the studied publishing houses. These objectives translated into the two research questions stated below:

RQ1: What roles have Nigerian Christian publishers assigned to themselves?

RQ2: To what extent, if any, do Nigerian Christian publishers invest in editorial capacity building?

The data generated that helped the researchers to answer these research questions are presented below in three histograms, two tables, and one pie chart designated as Tables 1 and 2; and Figures 1,2, 3 and 4 with the accompanying discussions.

Research Question One sought to determine the driving force for the engagement of Nigerian Christian publishers. Data generated in Table 1, and Figures 1 and 2 answer this research question.

Table 1: Availability of organisational philosophy

\begin{tabular}{|l|l|l|l|}
\hline & Yes & No & Total \\
\hline Mission Statement & $84(95.5 \%)$ & $4(4.5 \%)$ & $88(100 \%)$ \\
\hline Core Values & $76(86.4 \%)$ & $12(13.6 \%)$ & $88(100 \%)$ \\
\hline Editorial Policy & $72(81.8 \%)$ & $16(18.2 \%)$ & $88(100 \%)$ \\
\hline
\end{tabular}

Table 1 is a representation of the availability of three critical tools for the determination of the organisational philosophy of any publishing house. These tools are, Mission Statement, Core Values, and Editorial Policy. Each of the houses was asked to indicate whether it had those tools as a guide for the day to day operation of her activities. Encapsulated in these tools of organisational philosophy are the roles which such publishing houses have defined for themselves. Each of the three items of inquiry maintained high scores of above $70 \%$ which in conventional performance grading is designated with the letter notation $\mathbf{A}$, indicating an excellent performance. The implication is that Christian publishers in Nigeria are equipped with the basic philosophical instruments of operation.

To have a total picture of how the publishing houses were able to define their roles, the researchers also probed into the reasons for which the publishing houses were established. This is an overt indicator of role definition. Three indicative factors were considered, namely, evangelism, social service and return on investment. Figure 1 is a graphic presentation of the data.

The publishing houses give evangelism the first place as the reason for which they are established. This has $94.5 \%$ while Social service and return on investment placed second and third with $89.7 \%$ and $70.5 \%$ respectively. This corroborates the data in Table 1, as it confirms the fact that Christian publishers in Nigeria are quite aware of their goal of mission service. They fit into the prescription given by Obiora (1996) that a Christian publisher is:

One who gives hope and courage, ...promotes society's good morals...helps to promote and find the truth about this world, about God, about society, about life and its meaning, about nature and about humankind in general, and about the human person who is to be explored more deeply and become better understood as an image of God (p. : 93) 


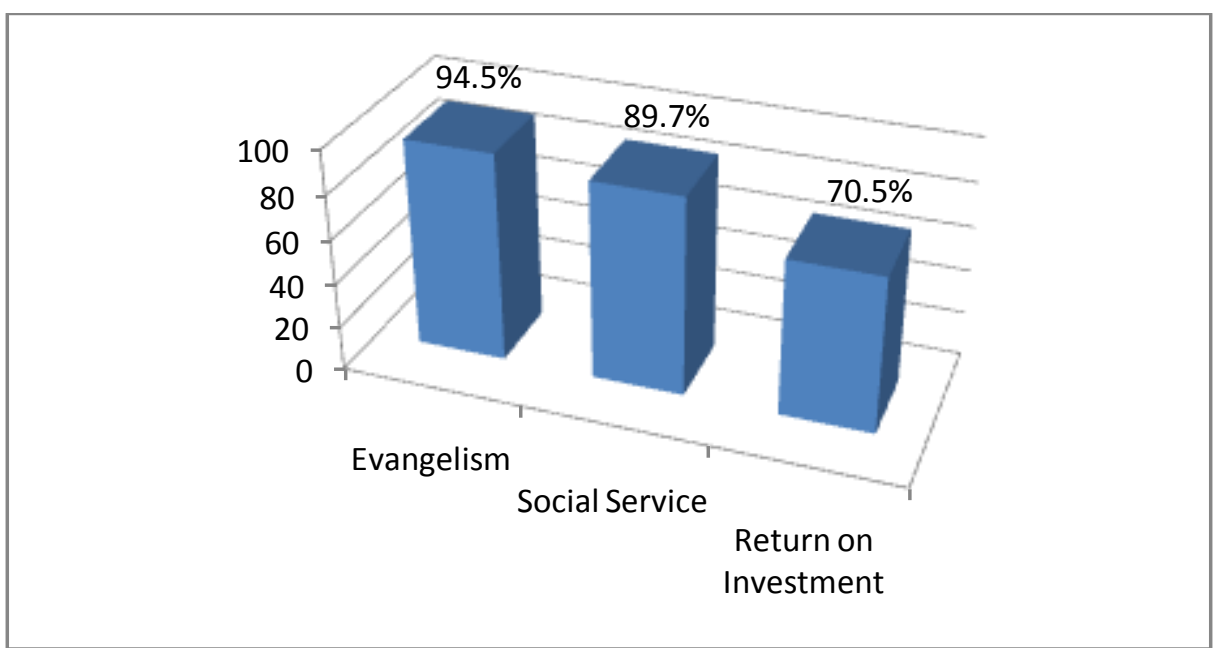

Figure 1: Reasons for establishing the publishing houses

In order to reach a proper conclusion on the ability of the publishing houses to define their roles, the researchers also probed into the values these publishing houses place on their publications. Figure 2 provides the data for this. Three key areas of content value were considered. These are the ability of the books to help readers lead good lives, help non-Christians understand and accept the Christian faith, and nurture the faith of professed Christians. These projected values were rated $95.4 \%$ for being able to help the readers lead a good live and 90.9\% each for being able to help non-Christians understand and accept the Christian faith as well as nurturing the faith of professed Christians.

The overall position of the publishing houses on the content of their books is in agreement with the stance of Wemter (1996, p. 87). For him, Christian books must be of relevance to both Christians and nonChristians alike. He maintains that Christian publishers should use their publications to further the cause of the gospel both within and outside the Church. This he maintains when he says that 'the Church must be able to authentically present itself to its own members and can do that only through its own publications, which hopefully will also attract people outside the church; if the people do not come to you, you must go to them'.

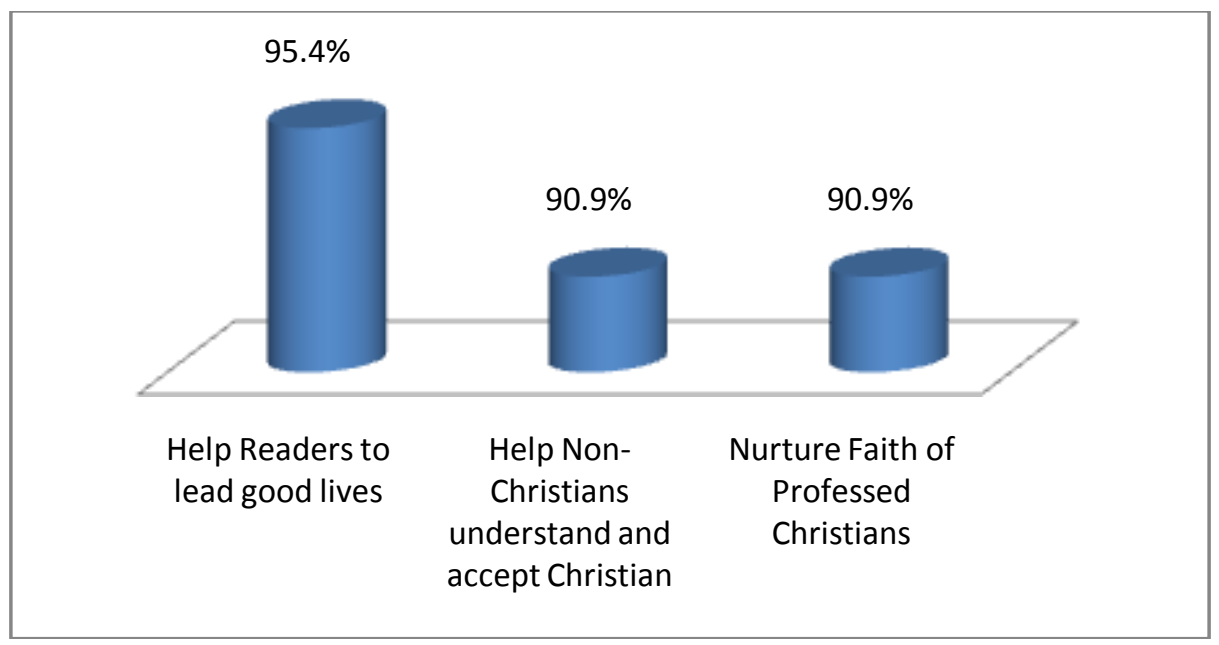

Figure 2: Content value of the books

Based on available data so far discussed, an affirmative answer need be given on the issue of whether Christian publishing houses in Nigeria are operating on defined roles. Indeed they are aware of their expectations as soul winners. They are determined on meeting the spiritual needs of their target audience through their publications.

Research Question Two sought to find out the extent of investment the publishing houses are making in respect of editorial capacity building. In this regard, the researchers are examining the strength of the publishing houses in the area of how many editors are in their employ and the extent to which they give these editors the opportunity of training for skills improvement. The data generated for this are presented in Tables 2 and 3 as well as in Figures 3 and 4 with the necessary discussions. 
Table 2: Editorial staff holding of the publishing houses

\begin{tabular}{|l|l|l|l|l|l|l|}
\hline & 1 & 2 & 3 & 4 & None & total \\
\hline Full time & $6(6.8 \%)$ & $7(8 \%)$ & $3(3.4 \%)$ & $3(3.4 \%)$ & $69(78.4 \%)$ & $88(100 \%)$ \\
\hline Part time & $3(3.4 \%)$ & $3(3.4 \%)$ & & $3(3.4 \%)$ & $79(89.8 \%)$ & $88(100 \%)$ \\
\hline Volunteer & $25(28.4 \%)$ & $22(25 \%)$ & $3(3.4 \%)$ & $4(4.5 \%)$ & $34(38.6 \%)$ & $88(100 \%)$ \\
\hline
\end{tabular}

Table 2 shows the nominal editorial staff list of the publishing houses and the status of their services in terms of full time, part time or volunteer services. In determining the editorial staff holding strength of the publishing houses, the data in Table 2 are summed up for each group of editorial strengths and compared on an availability and non-availability basis. The pie chart indicated as Figure 3 makes this clearer.

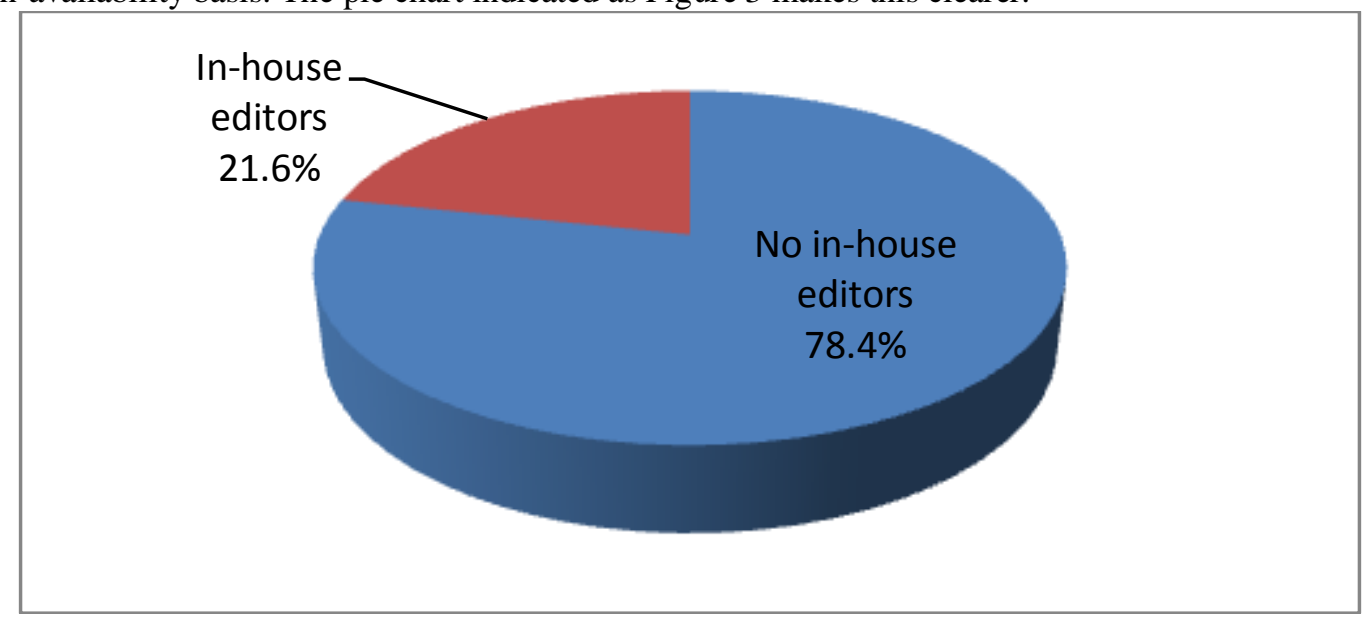

Figure 3: Pie chart showing availability of in-house editors

Figure 3 reveals that $78.4 \% \%$ of the publishing houses do not have any in-house editor. The implication on publishing output is quite obvious. For meaningful publishing to take place there should be a sizeable editorial work force. Where it is not possible to retain the required number of editors in a typical publishing house, resort may be made to part-time editors. The researcher therefore probed into this and the result showed that only $3.4 \%$ of the publishing houses have up to four such group of editors. Since these are publishing persons who share the same faith affiliation with the publishing house volunteering to perform editorial duties. The data in Table 2 confirmed this as $28.4 \%$ and $25 \%$ of the houses have one and two respectively of volunteer editors.

The situation is even more precarious when training opportunities for editorial staff in these publishing houses is considered. Four major training opportunities were considered. Table 3 reveals that of the four training categories, it is only one, that is, in-house training that is fairly available.

Table 3: Availability of training opportunities

\begin{tabular}{|l|l|l|}
\hline & Yes & No \\
\hline In- house training & $37(42 \%)$ & $51(57.9 \%)$ \\
\hline Professional conferences \& workshops & $20(22.6 \%)$ & $68(77.2 \%)$ \\
\hline Short-term external training & $31(35.2 \%)$ & $57(64.8 \%)$ \\
\hline Long-term external training & $22(25 \%)$ & $66(75 \%)$ \\
\hline
\end{tabular}

Figure 4 is a graphic translation of Table 3; this is done for clarity of discussion..

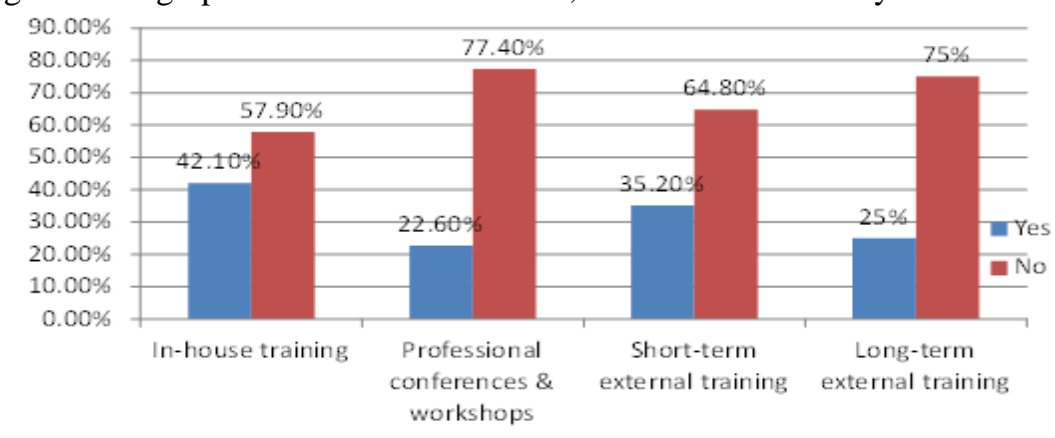

Figure 4: Availability of training opportunities 
The data generated in Tables 1 and 2 are quite revealing. Two major components of editorial capacity building in a publishing house are staff recruitment and training (Kyomuhendo, 2002). It is when a publishing house has recruited the requisite number and categories of editors and provides regular training opportunities for them that the house can boast of editorial capacity (Adejuwon, 2003; Fasemore, 2005). It is in this light that the research instrument for data gathering focused on these two aspects.

The implication of the above findings is that the editors are ill-equipped by way of training to face the challenges of their job. Although Christian religious publishing houses are not established for profit motive but for evangelism and witnessing, they nonetheless, are expected to perform productively in a competitive market. Working in a background of weak editorial capacity building base is an indicator of poor editorial management. It is a very vulnerable position.

When the performance effect of this low investment in editorial capacity building is measured by the standards set by Adesanoye (1995) for secular publishers it will reveal a more shocking result. No matter the level of professional training that an editor comes into a publishing house with, there is always the need for training and retraining. This is in order to keep the editor abreast of current trends in the industry as well as sharpen the already acquired skills on a daily basis (Okere, 2011).

\section{Recommendations}

In view of the findings in this research and in an effort to design appropriate editorial capacity building strategies for the survival of Christian faith-based publishing houses in Nigeria, the researchers are making the following recommendations:

1. If any publishing house desires to meet its goals, such a house must recruit the requisite editorial staff, not just as volunteers, but as professionals who have to meet the demand of service delivery. The idea of using volunteer editors smacks of exploitation or quasi entrepreneurship. This should be discouraged.

2. Whether the proprietors are ready to sponsor the editors or not, the editors themselves should make their own efforts to do some self sponsorship at least on short term courses. This will ensure a more efficient productivity.

3. One proactive necessary measure that will restore the dignity of publishing whether secular or religious is the need to standardise requirements for establishing a publishing house. An essential element in this is the stipulation of minimal number of editors that can guarantee the take-off of a particular publishing house. This is where Nigerian Publishers Association must rise up to the challenge of ensuring the professionalisation of publishing. When this is done, it will have the clout to accredit and proscribe publishing houses as the case may be.

\section{Conclusion}

Nigeria is a fertile ground for the patronage of Christian faith-based publications. Christian faith-based publishing on its own has a deep root in Nigerian publishing history. It was Christian initiative that laid the foundation for organized publishing in Nigeria. This was through the pioneering efforts of Reverend Hope Masterton Waddell of the Presbyterian Church and Reverend Henry Townsend of the Church missionary Society. While Hope Waddell began his publishing activities in 1846 in Calabar, Henry Townsend stated his in 1859 in Abeokuta. The pioneering effort of these missionaries is a strong heritage for contemporary Christian faith-based publishing in Nigeria.

Furthermore, in the last ten years, Christianity has made giant strides in the Nigerian socio-economic environment. Christian denominations and individuals with Christian faith base are contributing greatly to the educational development of the country by establishing various categories of educational institutions. This is an eloquent testimony that Christian initiative can sustain entrepreneurship. If these same groups can apply the same amount of energy towards the publishing houses there will be a tremendous turn around. What is required therefore of the publishing houses is a deliberate effort to reposition their operational base in terms of editorial manpower recruitment and training. That they have not invested maximally in editorial capacity building as the findings reveal is quite glaring.

\section{References}

[1] Kyomuhendo, G. (2002). Writing and Publishing in Africa. In M. Jay, \& S. Kelly, (Eds.). Courage and consequence: Women publishing in Africa. (pp.87-94). Oxford: African Books Collective

[2] Fasemore, A. (2005). Training the requisite book publishing personnel: Challenges and prospects. In F. Adesanoye \& A. Ojeniyi (Eds.). Issues in book publishing in Nigeria: Essays in honour of Aigboje Higo at 70 (pp.219-226). Ibadan: Heinemann Educational Books.

[3] Adejuwon, C, (2003). Building the total editor in response to quality in book production In C. Adejuwon (Ed.). Quality Book Production (pp.12-26). Ibadan: Codat Publications

[4] National Bibliography of Nigeria (2009)

[5] Bloisi, W. \& Cook, C. (2003). Management and organizational behaviour. New York: McGraw Hill Companies

[6] Kroepel R., (2005). What is philosophy. From http://www.bobkwebsite.com/whatisphilosophy.html\#What_is_Philoso phy 
[7] Cummings, T., \& Worley, C. (1997) Organization development and change (6th edition).

[8] Bagozzi.R., Jose.A., Sawhney, C., \& Francisco C. (1998) Marketing management.

[9] Bearden W., Ingram T., \& Laforge R. (2001): Marketing principles and perspectives. Education

[10] Hill C., \& Jones G. (2008) Strategic management. New York: Haughton Mifflin Company management. New Delhi: Prentice Hall of India.

[11] Cravens, D., \& Piercy, N. (2006). Strategic marketing ( $8^{\text {th }}$ edition).

[12] New York. McGraw Hill companies

[13] Noe, R., Hollenbeck, J., \& Gerhart, B, (2000). Human resource management: Gaining a competitive advantage (3 ${ }^{\text {rd }}$ edition). USA: McGraw Hill Companies

[14] Roman, G. \& Scott, W. (2003), The successful marketing plan: A disciplined and comprehensive approach. New York: McGraw Hill company, Inc.

[15] Talbot, M. (2000). Make your mission statement work: How to identify and promote the values of your organization. New Delhi: UBS Publishers Distributors Pvt. Ltd.

[16] Yesufu, T. (2000). The human factor in national development. Benin City, Nigeria: University of Benin Press and Spectrum Books Ltd.

[17] Chandan, J. (2000). Management: Theory and practice. New Delhi: Vikas Publishing

[18] Silver, G. (1981).Introduction to management. Minn. USA: West Publishing

[19] [20] Obiora, I. (1996). Catholic publishers as evangelizers through promoting education, development, justice and peace. In R. Boisvert, \& T. Marcazzan (Eds). Publishing at the service of evangelization (.Pp. 88-100). Nairobi, Kenya: Paulines Publications Africa.

[20] Wemter, O. (1996). How to integrate the editorial plan in the national pastoral programme. In R. Boisvert, \& T. Marcazzan (Eds). Publishing at the service of evangelization (pp.78-87). Nairobi, Kenya: Paulines Publications Africa.

[21] Adesanoye, F. (1995). Editing the editor's own English: Some observations on the literacy of the Nigerian book editor. The Publisher, 3(1), pp. 38-43

[22] Okere, S. (2011). The challenge of utilizing information and communication technology in book editing: A study of select publishing houses in Nigeria. Journal of research in national development, 9(.2b) pp. 262-269 also accessible at $\underline{\text { www.transcampus.org/journal and www.ajol.info/journals/jorind }}$ 